www.jmscr.igmpublication.org

Impact Factor 5.244

Index Copernicus Value: 5.88

ISSN (e)-2347-176x ISSN (p) 2455-0450

crossref DOI: _http://dx.doi.org/10.18535/jmscr/v4i3.06

Journal Of Medical Science And Clinical Research

\title{
Role of PPAR Gamma in obesity and obesity induced DM type-2
}

\author{
Authors \\ Manish Malhotra, S.M. Raju \\ Department of Biochemistry, SRMS IMS, Bareilly \\ Corresponding Author \\ Dr. Manish Malhotra \\ JR-III, MD (Biochemistry), Department of Biochemistry, SRMS IMS, Bareilly \\ Email: drmanishmalhotra83@gmail.com
}

\begin{abstract}
PPAR- $\gamma$ plays a critical role in glucose homeostasis and is a molecular target of insulin sensitizing drugs called thiazolidinediones which are PPAR- $\gamma$ ligands ${ }^{(3) .}$ PPAR- $\gamma$ ligands also upregulate expression of adipocyte glycerol kinase, resulting into improved insulin action in target tissue such as liver and muscle ${ }^{(4) .}$ PPAR- $\gamma$ ligand also shown to augment glucose disposal in peripheral tissues by increasing expressions of the glucose transporter genes, GLUT-1 and GLUT-4 ${ }^{(5}$ Majority of the Diabetes Mellitus Type 2 (DM type 2) patients (80\%) are obese, but all obese persons do not develop DM type 2. Serum adiponectin level should be determined by level of PPAR- $\gamma$ activity in adipocytes.

Therefore it will be of interest to explore the difference in the level of serum PPAR- $\gamma$ level between obese subjects with DM-2 and without DM-2, as both the insulin sensitizing factor's adiponectin, and vistafin are synthesized in response to FFA. PPAR- $\gamma$ complex receptor activity.

Estimation of serum PPAR- $\gamma$ level alongwith FBG was done in 90 cases, of which 30 were normal healthy subjects, 30 obese without diabetes type 2 and 30 obese with diabetes type 2 . The qualitative estimation of PPAR-y in human serum was done by ELISA method using ELISA kit from E lab science Biotechnology co.ltd. In our study we found a significant change in the level of PPAR- $\gamma$ between the obese with DM-2 and control subject and also between obese without DM-2 and control subject but we did not find any significant difference between obese with DM-2 and obese without DM-2

In our present study we found the Increased Levels of PPAR- $\gamma$ in the Obese without Diabetes Mellitus and Obese with Diabetes Mellitus. The levels were $8.03 \mathrm{ng} / \mathrm{ml} \pm 11.16$ and $8.04 \mathrm{ng} / \mathrm{ml} \pm 10.94$ respectively.

Finally, we observed that the level of PPAR- $\gamma$ is increased with both the groups, i.e .obese without DM-2 and obese with DM-2 in comparison to normal subjects.
\end{abstract}




\section{INTRODUCTION}

Diabetes Mellitus (DM) comprises a group of metabolic disorders characterized by Hyperglycaemia due to insufficient or inefficient insulin. There occur various types of DM that are caused by the interaction of genetics, environmental factors and life-style choices..The metabolic dysregulation associated with DM causes secondary pathophysiological changes in multiple organ system ${ }^{(1) .}$

Depending upon the etiology of DM, factors contributing to hyperglycaemia may include reduced insulin secretion, decrease glucose usage, and increased glucose production.

Adipose tissue produces a host of other substances (adipokines) that control the activity of cells in other tissues. The release of these adipokines come under the influence of insulin and these are abnormally released in the presence of obesity ${ }^{(2)}$ The adipokines shown to cause insulin resistance are: leptin, myostatin, resistin, and tumor necrosis factor-alpha. Peroxysomal Proliferative Receptor- $\gamma$ (PPAR- $\gamma$ ), adiponcetin, ATGL, and vistafin have been reported to increase the insulin sensitivity.

PPAR- $\gamma$ plays a critical role in glucose homeostasis and is a molecular target of insulin sensitizing drugs called thiazolidinediones which are PPAR- $\gamma$ ligands ( ${ }^{3)}$ PPAR- $\gamma$ ligands also upregulate expression of adipocyte glycerol kinase, there by stimulating fatty acid incorporation into triglyceride even under condition which would favour lipolysis and resulting into improved insulin action in target tissue such as liver and muscle ${ }^{(4)}$. PPAR- $\gamma$ ligand also shown to augment glucose disposal in peripheral tissues by increasing expressions of the glucose transporter genes, GLUT-1 and GLUT$4^{(5)}$.

They profoundly alter gene expression in adipose tissue .Expression of Resistin and TNF- $\alpha$ are reduced while expression of adiopnectin is increased by PPAR- $y$.
Human subjects harbouring (naturally occuring) mutations and polymorphisms within the PPAR- $\gamma$ genes have been indentified ${ }^{(6)}$. These mutations and ploymorphism in PPAR- $\gamma$ protein have been found to be linked with variations in the mammalian glucose homeostasis, lipid metabolism, and regulation of fat mass. Thus the quantitative as well as qualitative changes in PPAR- $\gamma$ protein may be responsible for obesity and obesity induced diabetes.

\section{AIMS AND OBJECTIVES}

Majority of the Diabetes Mellitus Type 2 (DM type 2) patients (80\%) are obese, but all obese persons do not develop DM type 2. In obesity the final determining factor for the development of DM-2 is serum leptin and serum adiponectin level. Serum leptin/serum adiponectin ratio should be directly related with DM-2.

Serum adiponectin level should be determined by level of PPAR- $\gamma$ activity in adipocytes.

Therefore it will be of interest to explore the difference in the level of serum PPAR- $\gamma$ level between obese subjects with DM-2 and without DM-2, as both the insulin sensitizing factor's adiponectin, and vistafin are synthesized in response to FFA. PPAR- $\gamma$ complex receptor activity.

This will contribute to the understanding of biochemical cause of obesity and obesity induced DM-2 and will in turn help in the proper selection of antiobesity and hyperglycemic drugs and designing of the drugs.

Therefore we aimed to determine the level of PPAR- $\gamma$ in obese subjects with type $2 \mathrm{DM}$ and obese subject without type $2 \mathrm{DM}$ and control subjects. Comparison of the data in these groups will show the overall picture of changes in the factor for the development of type $2 \mathrm{DM}$.

\section{MATERIAL AND METHOD}

The present study has been conducted at the Department of Biochemistry, Shri Ram Murti Smark Institute of Medical Sciences (SRMS IMS), Bareilly U.P. India. 
Level of PPAR- $\gamma$ with lipid profiles and fasting Blood glucose in obese persons with DM type 2 and obese persons without DM type 2 along with normal (control) persons were estimated.

\section{Materials}

30 Adult normal persons, 30 Adult obese persons without DM type 2 and 30 Adult obese persons with DM type 2 were selected for the study.

BMI was measured for each subject and proposed biochemical parameters were estimated in their blood samples. The Subject chosen were not on any drug treatment during days of blood collection. Age of the subject was between 25-65 years.

Subjects were taken from out-patient Department and Indoor-patient Department of Medicine, SRMS IMS Bareilly U.P. India. Subjects were of both sexes coming from reasonable distance around Bareilly city, U.P. India. They were from lower and middle class of rural area having moderate physical activities, with vegetarian as well as non-vegetarian dietary habits.

The Height (meters), weight $(\mathrm{kg})$ and BMI were recorded. Obese subjects had a BMI equal or greater than 25 and normal subject had a BMI less than 25. The waist (waist circumference was measured with a soft tape a standing subject mid way between the lower rib and iliac crest) (hip circumference was measured over the widest part and gluteal region) and therefore waist to hip ratio measured.

The detailed history of all the subjects were taken, and it was insured that the patient were not any drug treatment and were on overnight fasting for statistical significance and comparison, all these cases were divided into four different groups.

\section{Group-1: Control Group}

Serum PPAR- $\gamma$ level along with lipid profile and fasting Blood glucose was done in 30 normal healthy individuals of both sexes. Each individual of this group was examined clinically and was included in the study after finding them a normal individual.
Group-2: Obese Group: Serum PPAR- $\gamma$ level along with lipid profile and fasting Blood glucose was estimated in 60 cases of obese persons.

\section{Group-3: Obese without DM type-2}

Out of 60 cases of obese, 30 were obese without DM type-2 selected as the basis of fasting Blood glucose level.

\section{Group-4: Obese with DM type-2}

Out of 60 cases of obese, 30 were obese with DM type-2, selected on the basis of fasting Blood glucose level.

\section{Patients:}

Patients included in the study were having:

1. All the patients were without any drugs treatment during blood sample collection.

2. Had some symptoms of Diabetes Mellitus.

3. Obese on the basis of BMI i.e. more than 25

\section{Exclusion Criteria:-}

1. Cases taking same drug treatment for same disease.

2. Cases suffering from chronic diseases. Following estimation were done in Department of Biochemistry, SRMS IMS Bareilly U.P. India.

3. Fasting Blood Glucose level in serum.

4. Serum PPAR- $\gamma$

Local Research Ethic Committee approval was taken for the study before it commenced. Written consent was taken from the subject included in the study.

\section{SAMPLE PROCESSING}

Before collecting venous blood sample using standard venipuncture into vial subjects were asked to have a fasting period of 12 hrs. for the standardization blood was drawn in sitting position from anticubital vein. These samples were collected in three different wails. one for measuring Blood glucose (fasting) in sodium fluoride vial are plain vial for measuring factor included in the study i.e. PPAR- $\gamma$. Blood was allowed to clot and was immediately centrifuged at 5000rpm for 10 minutes. Serum was collected 


\section{JMSCR Vol||04||Issue||03||Page 9626-9632||March}

and stored immediately at $-20 \mathrm{c}$ until assay performed.

\section{METHODOLOGY}

The estimation of Serum glucose, lipid profile and PPAR- $\gamma$ was done by the following method.

\section{Serum fasting blood glucose}

Method of Fasting Blood Glucose Estimation (FBG) FBG was estimated by enzymatic method, making use of Glucose oxidase and Peroxidase (GOD-POD) method as described by Trinder. (1969)

\section{Method of Serum PPAR- $\gamma$ Level Estimation:-}

The qualitative estimation of PPAR- $\gamma$ in human serum was done by ELISA method using ELISA kit from E lab science Biotechnology co.ltd.

Table 1: Statistical analysis of level of PPAR- $\gamma$ in obese cases with DM-2 and control group. ( Non obese non Diabetic)

\begin{tabular}{|l|c|l|l|l|l|l|}
\hline \multicolumn{1}{|c|}{ Group } & No. of cases & \multicolumn{2}{|c|}{ PPAR- $\boldsymbol{\gamma}(\mathbf{n g} / \mathbf{m l})$} & \multirow{2}{*}{ P-value } & Remark \\
\cline { 3 - 6 } & & Range & Mean & SD & & \\
\hline $\begin{array}{l}\text { Obese with DM } \\
\text { Type 2 }\end{array}$ & 30 & $0.1-35.6$ & 8.04 & 10.94 & 0.008 & S \\
\cline { 1 - 5 } $\begin{array}{l}\text { Control group- Non } \\
\text { obese Non Diabetic }\end{array}$ & 30 & $0.2-8.1$ & 2.45 & 1.99 & & \\
\hline
\end{tabular}

Table shows level of PPAR- $\gamma$ in obese with DM-2 varies from $0.01 \mathrm{mg} / \mathrm{dl}$ to $35.6 \mathrm{mg} / \mathrm{dl}$ with mean $8.04 \mathrm{mg} / \mathrm{dl}$ and control group varied from $0.2 \mathrm{mg} / \mathrm{dl}-8 \mathrm{mg} / \mathrm{dl}$ with mean $2.45 \mathrm{mg} / \mathrm{dl}$. The difference in the level of PPAR- $\gamma$ between obese with DM-2 and control group is significant ( $p$ value 0.008 )

The estimation of serum PPAR- $\gamma$ level and serum lipid profile alongwith FBG was done in 90 cases, of which 30 were normal healthy subjects, 30 obese without diabetes type 2 and 30 obese with diabetes type 2 .
The subjects included both sexes, vegetarian as well as non vegetarian, engaged in moderate physical activity, with age ranging from 25-65 years and of economically lower to middle class, from mostly the rural areas around Bareilly, U.P. India.

In our present study we found the Increased Levels of PPAR- $\gamma$ in the Obese without Diabetes Mellitus and Obese with Diabetes Mellitus.

The levels were $8.03 \mathrm{ng} / \mathrm{ml} \pm 11.16$ and $8.04 \mathrm{ng} / \mathrm{ml} \pm 10.94$ respectively.

Table2: Statistical analysis of level of PPAR- $\gamma$ in obese cases with and without DM Type-2

\begin{tabular}{|l|l|l|l|l|l|l|}
\hline \multirow{2}{*}{ Groups } & \multirow{2}{*}{ No. of cases } & \multicolumn{2}{l|}{ PPAR- $\boldsymbol{\gamma}(\mathbf{n g} / \mathbf{m l})$} & \multirow{2}{*}{ P-value } & \multirow{2}{*}{ Remark } \\
\cline { 2 - 5 } & & Range & Mean & SD & & \\
\hline Obese without DM Type 2 & 30 & $0.1-36$ & 8.03 & 11.16 & 0.99 & \multirow{2}{*}{ NS } \\
\hline Obese with DM Type 2 & 30 & $0.1-35.6$ & 8.04 & 10.94 & & \\
\hline
\end{tabular}

Table show level of PPAR- $\gamma$ in obese with DM-2 varied from $0.1 \mathrm{ng} / \mathrm{dl}$ to $35.6 \mathrm{ng} / \mathrm{dl}$ with mean 8.04 $\mathrm{ng} / \mathrm{ml}$ and in obese without DM-2 varied from $0.1 \mathrm{ng} / \mathrm{ml}$ to $36 \mathrm{ng} / \mathrm{ml}$ with mean $8.03 \mathrm{ng} / \mathrm{ml}$. The difference in the level of PPAR- $\gamma$ between obese with DM type-2 and obese without DM-2 is not significant ( $p$ value 0.99 ) The estimation of serum PPAR- $\gamma$ level and serum lipid profile alongwith 
FBG was done in 90 cases, of which 30 were normal healthy subjects, 30 obese without diabetes type 2 and 30 obese with diabetes type 2 .

The subjects included both sexes, vegetarian as well as non vegetarian, engaged in moderate physical activity, with age ranging from 25-65 years and of economically lower to middle class, from mostly the rural areas around Bareilly, U.P. India.

In our present study we found the Increased Levels of PPAR- $\gamma$ in the Obese without Diabetes Mellitus and Obese with Diabetes Mellitus.

The levels were $8.03 \mathrm{ng} / \mathrm{ml} \pm 11.16$ and $8.04 \mathrm{ng} / \mathrm{ml} \pm 10.94$ respectively.

\section{DISCUSSION}

PPAR $-\gamma$ is a nuclear hormone receptor that comprises an agonists -dependent activation domain, DNA binding domain, agonists independent activation domain. It is expressed predominantly in adipose, tissues. Synthetic agonists of PPAR $-\gamma$, thiazolidinediones (TZDs), have been developed to improve glucose tolerance by enhancing insulin sensitivity and restoring the function of beta cells in diabetic subjects.

Patients with a dominant -negative mutation in the PPAR- $\gamma$ gene show severe hyperglycaemia, which provides a genetic link between PPAR- $\gamma$ and type 2 diabetes. Now in Obese without Diabetes subjects, the increased level of PPAR $\gamma$ is due to increased Insulin Resistance due to Obesity.

Now in Obese with Diabetes subjects the increased level of PPAR- $\gamma$ is due to the prevalence Insulin Resistance, as Insulin Resistance is getting high and high expression of PPAR- $\gamma$ is also getting high in accordance to Insulin Resistance. When Insulin Resistance become so high that beta cell of Pancreas cannot produce enough Insulin to maintain Euglycaemia overt Diabetes develops.So in these group of patients also there is an elevated level of plasma PPAR- $\gamma$ is seen. So from above findings we can conclude that PPAR- $\gamma$ is a predominantly Insulin sensitizing agent, as Insulin
Resistance is increasing the expression of PPAR$\gamma$ is also significantly rises.

PPAR- $\gamma$ ligands increase the expression of both Lipoprotein lipase (LPL), which releases free fatty acids transporters, phosphoenolpyuvate carboxykinase and Glycerokinase which results in greater FFA flux into the adipocytes .These fatty acids are esterified into triglycerides.

The similar kind of result was found in the study done by,(PPAR- $\gamma$ igands), affect LPL expression in a tissue-specific manner and to investigate the relative contribution of the various PPAR subtypes to these regulatory events. We have chosen to use LPL as a target gene in these studies because a number of clinical studies suggested that the triglyceride lowering action of fibrates and polyunsaturated fatty acids is associated with an increase in LPL activity ${ }^{(7) .}$ The LPL 5' regulatory sequences indicated that LPL induction was mediated by a response element, located between -157 and -169 in the human LPL gene.

Studies showed lipid metabolism that PPAR-RXR heterodimers bind to the response element in the human and mouse ${ }^{(8,9) .}$ The tissue-selective effects of the PPAR activators/ ligands are highly intriguing and provide insight into their effects on triglyceride metabolism. Fibrate treatment induced LPL expression strongest in liver, whereas BRL49653 had no effect on liver, but induced adipocyte LPL expression. These compounds had no effect on heart LPL mRNA levels both in vivo and in vitro studies, inducibility of LPL mRNA expression by either PPAR-y or PPAR y activators correlated with the tissue-specific distribution of the respective PPARs.

s PPAR- $\gamma$ ligands, such as prostaglandins (Forman et al., 1995; Kliewer et al., 1995), which then could activate PPAR- $\gamma$ and induce LPL gene transcription. The slower kinetics of LPL mRNA induction after fenofibrate treatment is consistent with this hypothesis.

Lehmann et al 1995: Yu et al., 1995), are reported to activate PPAR $-\gamma$. Although to a lower extent 
than PPAR $-\gamma$ ligands. Identification of the natural ligands for all PPAR types, as well as the identification of high affinity synthetic agonists and antagonists, will most likely result in chemicals which will be more selective than the currently available compounds, allowing target gene activation in a specific tissue of interest while limiting undesired side-effects in other tissues. These compounds might have interesting therapeutic features, especially if one considers the context of the widespread use of fibrates in the treatment of diet resistant hyperlipidemia and the potential usefulness of thiazolidinediones in treatment of non-insulin-dependent diabetes.

Recent studies suggests that several signal transduction pathways are affected by thiazolidinediones, most notably protein tyrosine phosphatase activity ${ }^{(10)}$. The demonstration of a PPRE in the LPL gene has important implications for adipocyte physiology. The adipose-restricted PPAR $\gamma 2$ type can promote pre-adipocyte determination as well as terminal differentiation (Tontonoz et al., 1994a,b) .

The PPAR-mediated induction of LPL expression hence explains the mechanism by which the differentiation linked induction of LPL occurs. The observation that the LPL gene appears to be slightly more efficiently activated by PPAR$\gamma$ than by PPAR alpha (data not shown) is consistent with the specific role of PPAR $-\gamma$ in adipose differentiation(Tontonoz et al., 1994b; Brun et al., 1996 $6^{(11,12,13,14)}$. The increase in lipolytic capacity as a result of induction of LPL by PPAR- $\gamma$ will result in increased delivery of fatty acids to the adipocytes. This points to the possible existence of a positive regulatory feedback loop involving PPAR- $\gamma$ and LPL and aim at promoting and maintaining the mature adipocyte phenotype certain fatty acid-derived prostaglandin derivatives, whose delivery to the cell is increased by LPL, bind to and or activate PPAR- $\gamma$ (Forman et al., 1995; Kliewer et al., 1995; $\left.{ }^{(15}\right)$ Lehmann et al., 1995; Yu et al., 1995).

PPAR, which interacts with a PPRE in the LPL promoter. In adipose tissue, the increase in LPL production after treatment with thiazolidinediones will enhance the clearance of plasma triglycerides and provide the (pre-) adipocytes with additional fatty acids, which can further stimulate the trans activation capacity of PPAR or which can be stored in the form of triglycerides. In the liver, enhanced production of LPL, together with reduced production of apo C III.(Staels et al., 1995), may contribute to the hypolipidemic action of these compounds ${ }^{(16)}$. This tissue-selective induction of LPL gene transcription by activators of different PPARs demonstrates the feasibility of the development of highly specific PPAR sub type specific agonists and antagonists, which can be used as drugs.

\section{CONCLUSION}

Following conclusion can be drawn from the present study. In obese without DM-2 in comparison to normal healthy subjects- Serum PPAR- $\gamma$ level was increased which is similar as reported by others,. In obese with DM-2 in comparison with normal healthy subjects.

Finally, we observed that the level of PPAR- $\gamma$ is increased with both the groups, i.e.obese without DM-2 and obese with DM-2 in comparison to normal subjects.

\section{REFERENCES}

1. Harrison Principles of Internal Medicine $18^{\text {th }}$ Edition Volume $1 \& 2$

2. Eckel R., Grundy S. Insensitivity to insulin and obesity: the underlying cause, Diabetes Voice 2006; 51;28-30

3. Berger J.Leibowitz MD Doebber TW, et $a l$. novel PPAR $-\gamma \&$ PPAR $-\delta$ ligands produce distinct biological effect. $J$ bill Chem 1999; 274:6718-6725.

4. Gurnell, M., 2003. PPAR - $\gamma$ Modulation of Insulin Sensitivity - Potential Mechanisms. Clin Endocrinology. 59 (3)

5. Sokkar, S. Jehan, A., E1 - Sharnouby et al 2009. Role of PPAR - $\gamma$, Gene Polymorphism in Type 2 Diabetes 


\section{JMSCR Vol||04||Issue||03||Page 9626-9632||March}

Mellitus. European Journal of General Medicine 6 (2): 78-86.

6. Borroso I, Gurnell M, Crowley VE et al. Dominant negative mutations in human PPAR $-\gamma$ associated with, severe insulin resistance, DM, \& HTN. Nature 1999;402:880-883.

7. Schonfeld,G. (1994) The effects of fibrates on lipoprotein and hemostatic risk factors. Atherosclerosis, 111, 161-174.

8. OsumiT.. Wen.J.K. and Hashimoto,T. (1991) Two cis-acting regulatory elements in the peroxisome proliferator-responsive element enhancer region of rat acyl-CoA oxidase gene. Biochiemii. Biophys. Res. Com11u711n1.a.175, 866-871.

9. Kliever.S.A.. Forman.B.M.. Blumberg.B.. Ong.E.S.. Borgmeyer.U.. Mangelsdorf. D.J.. Umesono.K. and Evans.R.M. (1994) Differential expression and activation of a family of murine peroxisome proliferatoractivated receptors. Proc. Natl Acald. Sci. USA. 9. 7355-7359.

10. Maegawa,H._ Ide.R.. Hasegawa.M.. Ugi,S.. Egava.K., Iwanishi.M.. Kikkawa,R., Shigeta.Y. and Kashigawa,A. (1995) Thiazolidine derivatives ameliorate high glucose-induced insulin resistance via the normalization of protein-tyrosine phosphatase activities. J. Biol. Chem.. 270. 7724-7730.

11. Tontonoz,P., Hu,E. and Spiegelman,B.M. (1994b) Stimulation of adipogenesis in fibroblasts by PPARy2, a lipid-activated transcription factor. Cell, 79, 1147-1156.

12. Tontonoz,P., Hu,E., Devine,J., Beale,E.G. and Spiegelman,B.M.(1995)

13. PPARy2 regulates adipose expression of the phosphoenolpyruvate carboxykinase gene. Mol. Cell. Biol., 15, 351-357.

14. Brun,R.P., Tontonoz,P., Forman,B.M., Ellis,R., Chen,J., Evans,R.M. and Spiegelman,B.M. (1996) Differential activation of adipogenesis by multiple PPAR isoforms. Genies Dei., 10, 974-984.

15. Lehman.J.M. (1995) A prostaglandin J2 metabolite binds peroxisome proliferatoractivated receptor $\mathrm{y}$ and promotes adipocyte differentiation. Cell, 83. 813819.

16. Staels,B., Vu-Dac,N., Kosykh,V., Saladin,R., Fruchart,J.C., Dallongeville,J. and Auwerx,J. (1995) Fibrates downregulateapolipoprotein $\mathrm{C}$-1Il expression independent of induction ofperoxisomal acyl co-enzyme A oxidase. J. Clin. Invest., $95,705-712$ 